\title{
Highlights on Chaetomium morphology, secondary metabolites and biological activates
}

\author{
Waill A. Elkhateeb ${ }^{1}$, Abdu Ghalib AL Kolaibe ${ }^{2}$, Marwa O. EInahas ${ }^{1}$, Ghoson M. Daba ${ }^{1}$ \\ ${ }^{1}$ Chemistry of Natural and Microbial Products Department of Pharmaceutical Industries Division, National Research Centre, Dokki, Giza, 12622, \\ Egypt. \\ ${ }^{2}$ Microbiology Department, Faculty of science, Taiz University, Taiz, Yemen.
}

Corresponding Author: Waill A. Elkhateeb, Department of Pharmaceutical Industries Division, National Research Centre, Dokki, Giza, 12622, Egypt.

Received date: January 25, 2021; Accepted date: January 28, 2021; Published date: February 04,2021

Citation: Waill A. Elkhateeb, Abdu G. AL Kolaibe, Marwa O. Elnahas, Ghoson M. Daba (2021) Highlights on Chaetomium morphology, secondary metabolites and biological activates J. Pharmaceutics and Pharmacology Research 4(1); DOI: 10.31579/2693-7247/033

Copyright: ( 2021, Waill A. Elkhateeb, This is an open access article distributed under the Creative Commons Attribution License, which permits unrestricted use, distribution, and reproduction in any medium, provided the original work is properly cited.

\begin{abstract}
Endophytic fungi always attract attention due to their generous production of bioactive and chemically novel compounds that have medical, agriculture, industrial applications. This review focused on Chaetomium as a model of endophytic fungi rich in therapeutic agents that have known medicinal and industrial application. Moreover, understanding the importance of this potent fungus encourage further studies to identify novel metabolites, and at the same time employing already known metabolites to evaluate their activity in order to be used in additional applications.
\end{abstract}

Keyword: Chaetomium; Secondary metabolites; Biological activities, applications

\section{Introduction}

The application of microbial secondary metabolites in general, and fungal metabolites in particular in various fields of biotechnology has attracted the interests of many researchers, thanks to the bioactive properties of these metabolites which made them employed in various applications in pharmaceutical, industrial, and agricultural fields. Fungal endophytes are microorganisms that live inside the interior tissues of living plants without bringing on anydangerous reactions [1-4]. Generally, endophytes are generous source of novel and biologically active natural compounds with incredible healing potentials. Recently, remarkable pharmacological agents have been generated from endophytic fungi [5, 6]. More than 50\% of previously unknown biologically active substances have been isolated from endophytes [7]. Bio-pharmacological secondary metabolites originated from endophytes exhibit different antimicrobial, anticancer, antitumor, and anti-inflammatory activities [8]. The endophytic fungus, Chaetomium, is an excellent model that is used as a biotechnological tool in various fields. Chaetomium species are heterothallic fungi that found mainly in soil and organic compost and recently it was isolated from coral, soft coral, and marine algae, and Chaetomium are known for the production of secondary metabolites with vital biological activities. [914]. Different isolates of Chaetomium showed various mechanisms of antagonism against other pathogen fungi and they have been also reported to produce several antifungal metabolites $[15,16]$. As an example Chaetomium globosum Kunze Fr., has been identified as potential biocontrol agent against a numerous plant pathogens [17].

In this review, highlights on the description, ecology, biological activities and secondary metabolites produced by Chaetomium Species were presented.

\section{Chaetomium description and ecology}

The word 'endophytes' describes microbes colonizing internal living tissues of plants without causing any immediate harmful impacts [1]. Chaetomium sp. is a dematiaceous filamentous fungus that can be isolated found air, soil, and also from plant debris [18, 19]. Chaetomium belongs to the class Pyrenomycetes (Ascomycotina), Order Sordariales and family Chaetomiaceae. There are about 95 species that have been identified under the genus Chaetomium worldwide [20]. As well as being a contaminant, Chaetomium sp. are also encountered as human pathogen. Some species are thermophilic and neurotropic in nature [21]. Chaetomium sp. are common fungal species with a worldwide ubiquitous distribution and are widespread in soil and on decaying plant materials but spore concentrations in outdoor air are not very high. Indoors, Chaetomium is found on wood, compost, sheet rock, straw, and similar cellulosic materials. It is also known as a soft-rot fungus for softwood and hardwood timber [22]. Colonies of Chaetomium are fast growing, colonies appear whitish cottony at the beginning, and turn grey to olive in color when become mature. From the reverse, color appear to be reddish tan or brownish black [23]. Chaetomium is ascomata globose, ellipsoid to ovate or obovate, ostiolate or non-ostiolate in a few species, with walls usually composed oftextura intricata or epidermoidea in surface view, or of textura angularis in a few species. Ascomatal hairs hypha-like, flexuous, undulate, coiled to simply or dichotomously branched, with verrucose surface, or smooth in a few species (Figure 1,2). Asci clavate or fusiform with 8 biseriate or irregularly arranged ascospores, evanescent. Ascospores limoniform to globose, or irregular in a few species, bilaterally flattened, usually more than $7 \mu \mathrm{m}$ in length. Asexual morphs, if present, acremonium-like. Member of the genus Chaetomium 
are cosmopolitan and prevalent component of different ecosystem in a wide range of environments and climatic zone [24].

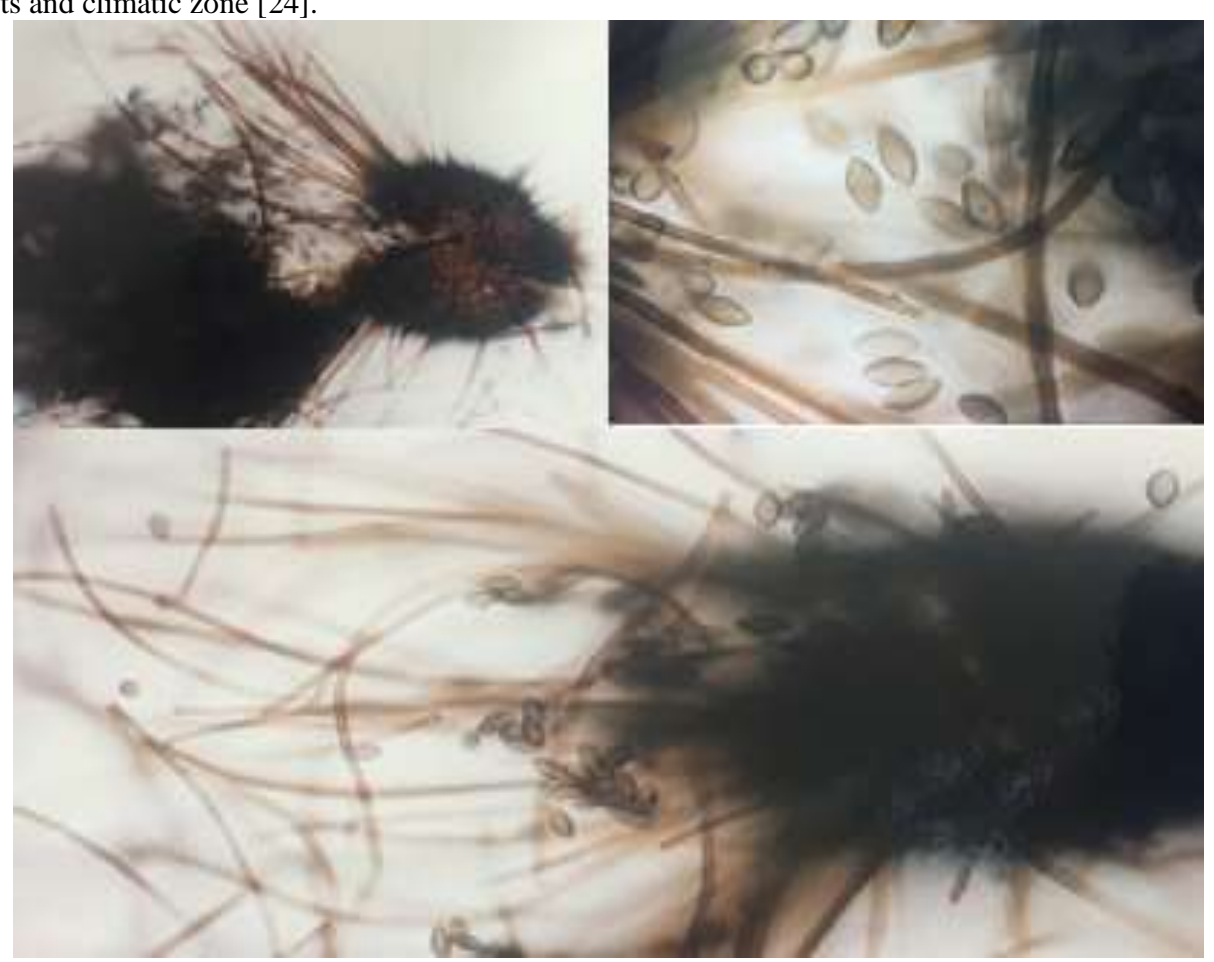

Figure 1. Chaetomium species with spiral setea and with oval ascospores. isolated and identified by Dr. Waill Elkhateeb (Photographs was taken by Dr. Waill A. Elkhateeb, Locality: National Research Center of Egypt).
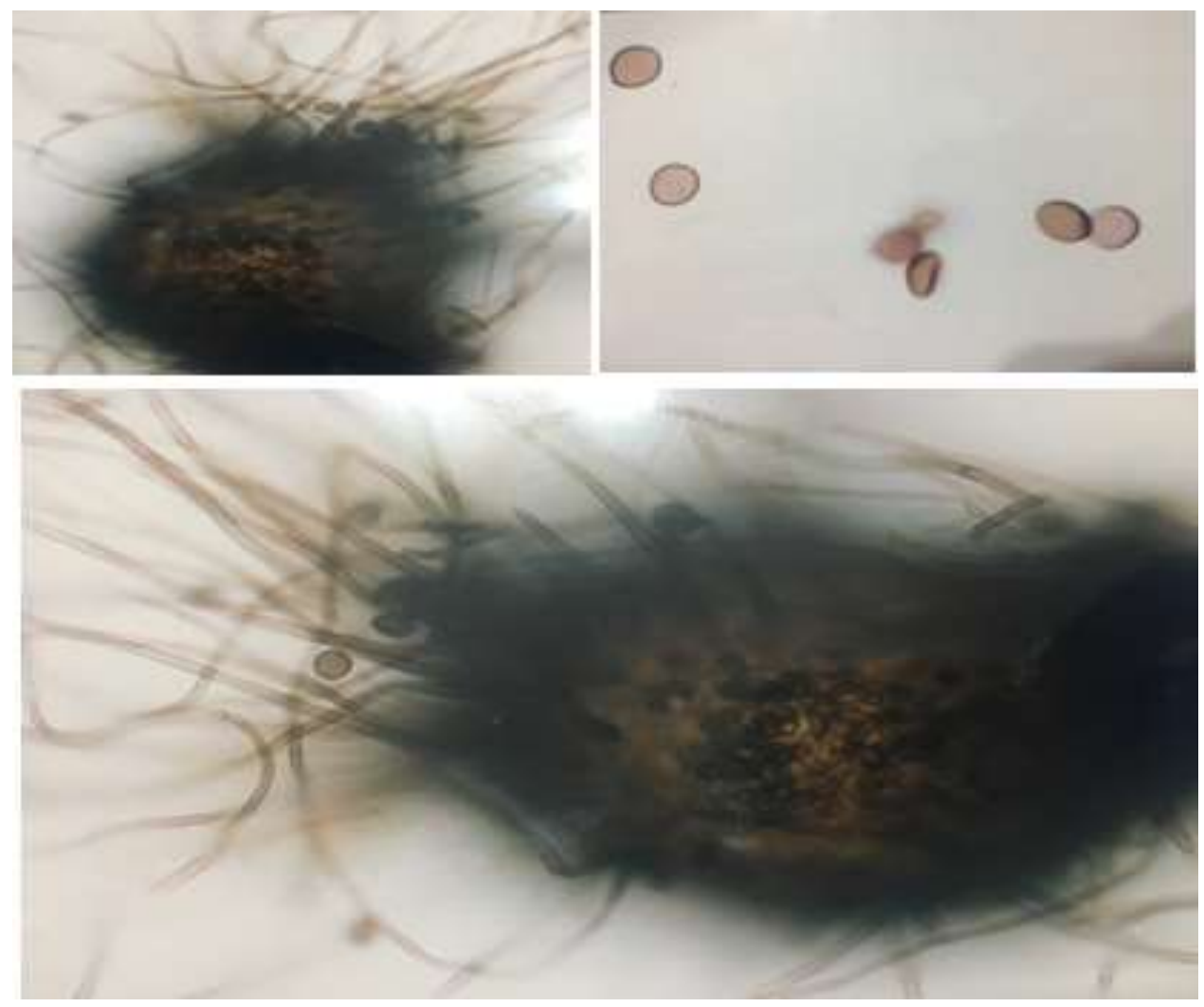

Figure 2. Chaetomium species with globosum ascospores isolated and identified by Dr. Waill Elkhateeb (Photographs was taken by Dr. Waill A. Elkhateeb, Locality: National Research Center of Egypt). 


\section{Chaetomium secondary metabolites}

Over 200 secondary metabolites were isolated and identified from Chaetomium globosum including terpenoids, chaetoglobosins, tetramic acids, steroids, xanthones, diketopiperazines, bis (3-indolyl)benzoquinones, azaphilones, anthraquinones, pyranones, and orsellides. Some of these metabolites exhibit various bioactivities such as cytotoxic, antimicrobial, antimalarial, anticancer, and antiviral activities.

Tawfik et al., [25] detected some compound which have investigate the anticancer and antimicrobial activity, The Metabolomics and bioassayguided isolation afforded five pure compounds; $\mathrm{p}$ hydroxybenzaldehyde, Uracil, 3-benzyl-6-isobutyl piperazine-2,5-dione, Cyclo (L-Alanin-L-leucin) and Cyclo-(L-proline-L-leucine) (Figure, 3).<smiles>O=Cc1ccc(O)cc1</smiles>

p-hydroxybenzaldehyde<smiles>CC(C)CC1NC(=O)C(C)NC1=O</smiles>

L-Alanin-L-leucin<smiles>O=c1cc[nH]c(=O)[nH]1</smiles>

Uracil<smiles>[3H]C(C)CC1NC(=O)C(Cc2ccccc2)NC1=O</smiles>

3-benzyl-6-isobutyl piperazine-2,5-dione

Figure 3. Some bioactive compounds produced by Chaetomium species.

\section{Some biological activities of Chaetomium metabolites}

Due to their generosity in production of secondary metabolites such as chaetoglobosins, xanthones, anthraquinones, terpenoids, depsidones and steroids, researches were conducted to evaluate the biological activities of those compounds [26, 27].

Chaetomium species have potent antimicrobial activities that encouraged their use as biocontrol agents. Many reports have described different species potency, (especially Chaetomium globosum) against Venturia inaequalis, the apple scab pathogen [28]; also against Macrophoma kuwatsukai, Rhizoctonia solani and Sclerotium rolfsii (Corticium rolfsii) $[29,30]$. Moreover, Chaetomium have promising antagonistic activities against the spot blotch pathogen, Drechslera sorokiniana [31, 32]. Furthermore, Chaetomium showed antifungal activities against Fusarium, Pyricularia oryzae, Helminthosporium, Pyrenophora, Pythium ultimum, Sclerotinia sclerotiorum; Cochliobolus sativus, Alternaria raphani, [33, 34]. Also, application of C. globosum as a biocontrol agent for controlling late blight disease in potato plants showed promising results and resulted in greater tuber yield. Similarly, it was reported that $C$. globosum could suppress the damping-off of sugar-beet caused by Pythium ultimum [35, 36]. On the other hand, Chaetomium species showed also good antibacterial activities against gram positive and negative bacteria especially Escherichia coli and Staphylococcus aureus [37].

The cytotoxicity and anticancer properties of Chaetomium species have also been described. For example, A new dihydroxanthenone was isolated from Chaetomium globosum showed anticancer activity against a panel of seven human solid tumor cell lines (Wijeratne et al., 2006). The polysaccharides obtained from Chaetomium globosum CGMCC 6882 showed anticancer activities against human lung Cancer A549 Cells [38]. Flavipin produced by Chaetomium globosum showed antiproliferative activity against A549, HT-29 and MCF-7 cancer cells in dose dependent manner with an IC50 concentration of $9.89 \mu \mathrm{g} / \mathrm{ml}, 18 \mu \mathrm{g} / \mathrm{ml}$ and $54 \mu \mathrm{g} / \mathrm{ml}$, respectively [39]. Two novel compounds (methyl 9-dihydro-8trihydroxy-9-oxo-Hxanthene-1-carboxylate as a member of xanthones and (E)-methyl 2-hydroxy-6, 6-dimethyl hept-3-enoate) extracted from Chaetomium globosum isolated from Egyptian soil showed anti-proliferation activities against MCF-7 human breast cancer cell line and HEPG-2 human liver carcinoma cell line [40].

It should be noted that co culturing specific bacterial species were reported to induce metabolites production by Chaetomium [41-44]. Chaetomium species exerted also promising nematicidal activities especially against Meloidogyne javanica, Heterodera glycines and Meloidogyne incognita [45-50].

\section{Conclusion}

Emerging of antibiotic resistant microbes, as well as new diseases that threaten human life, besides the growing awareness of the dangerous impacts of using chemicals for pests and fungal control, are serious that require continuous search for potent sources of potent compounds from natural sources.

Recently, biocontrol of soil-borne pathogens has attracted attention as a promising support or alternative to currently used harmful chemicals. Chaetomium species in general, and Chaetomium globosum in particular, represent promising biocontrol agents that can get rid of pathogens and 
increase yield. Understanding the nutritional needs, mode of action, and quantification of fungi in soils are important factors that require further studies.

Development and easiness of isolation, and molecular identification of Chaetomium have facilitate discovering new species. Also, progress in chemical methods of extractions and invention of advanced instruments for chemical identification of compounds have open the way for the discovery of novel compounds with potential biological activities.

Using molecular markers, in depth study of interaction between Chaetomium and other microorganisms as well as their host plants are topics that require additional researches. Further investigations on the results of co-culturing Chaetomium with different bacterial species and its impact on the resulting metabolites are of extreme importance. Finally, investigating the potential bioactivities.

\section{References}

1. Bacon CW, White JF. (2000). Microbial Endophytes, Marcel Dekker, New York; 2000: 4-5.

2. Mazen MB, Hashem M, Zohri AA, Elkhateeb WA. (2009). Study of the diversity, distribution and phytopathogenecity of phyllosphere and phylloplane mycobiota of new reclaimed areas at Assiut, Upper Egypt. Assiut University Journal of Botany, Special Publication, 1: 41-64.

3. Zohri AA, Elkhateeb WA, Mohamed B. Mazen, Hashem M, Daba GM. (2014). Survey of all mycobiota associated with rhizosphere and rhizoplane of different cultivated plants in new reclaimed soil, Upper Egypt and examination of the most common fungal isolates to produce mycotoxins. Egyptian Pharmaceutical Journal, 13(1): 64-70.

4. Zohri, AA, Elkhateeb WA, Mazen M, Hashem M, Daba. (2014). Study of soil mycobiota diversity in some new reclaimed areas. Egypt. Egyptian Pharmaceutical Journal, 13(1): 58-63.

5. Strobel G, Daisy, B. (2003). Bioprospecting for microbial endophytes and their natural products. Microbiol. Mol. Biol. Rev. 67: 491-502.

6. Daba GM, Waill A. Elkhateeb, Paul W. Thomas (2018). This era of biotechnological tools: an insight into endophytic mycobiota. Egyptian Pharmaceutical Journal, 17(3): 121-128.

7. Schulz B, Boyle C, Draeger S, Rommert AK, Krohn K. (2002). Endophytic fungi: a source of novel biologically active secondary metabolites. Mycol. Res. 106: 996-1004.

8. Aly AH, Debbab A, Proksch P. (2011). Fungal endophytes: unique plant inhabitants with great promises. Appl. Microbiol. Biotechnol. 90: 1829-1845.

9. Tveit M, Wood RKS. (1955). The control of Fusarium blight in oat seedling with antagonists species of Chaetomium. Annu Appl Biol., 43: 538-552.

10. Hawas UW, Fadl E, Halwany AA, Atif A, Elkhateeb WA, Abou El-Kassem LT. (2016). Bioactive metabolites from the Egyptian red sea fungi with potential anti-hcv protease effect. Chemistry of Natural Compounds, 52(1): 104-110.

11. Yan W, Cao LL, Zhang YY, Zhao R, Zhao SS, Khan B, Ye YH. (2018). New metabolites from endophytic fungus Chaetomium globosum CDW7. Molecules, 23(11): 2873.

12. Yu FX, Chen Y, Yang YH, Li GH, Zhao PJ. (2018). A new epipolythiodioxopiperazine with antibacterial and cytotoxic activities from the endophytic fungus Chaetomium sp. M336. Natural product research, 32(6): 689-694.

13. Elkhateeb WA, Daba GM. (2018). Where to Find? A Report for Some Terrestrial Fungal Isolates, and Selected Applications Using Fungal Secondary Metabolites. Biomed Journal Science \&Technology Research, 4(4): 1-4.
14. El-Kassem LA, Hawas UW, El-Souda S, Ahmed EF, El-Khateeb W, Fayad W. (2019). Anti-HCV protease potential of endophytic fungi and cytotoxic activity. Biocatalysis and Agricultural Biotechnology, 101170.

15. Aggarwal R, Tiwari AK, Dureja P, Srivastava KD. (2007). Quantitative analysis of secondary metabolites produced by Chaetomium globosum Krunze ex Fr. J Biol Control, 21:163168.

16. Aggarwal R, Tewari AK, Srivastava KD, Singh DV. (2004). Role of antibiosis in the biological control of spot blotch (Cochliobolus sativus) of wheat by Chaetomium globosum. Mycopathologia, 157(4): 369-377.

17. Vannacci G, Harman GE. 1987. Biocontrol of seed borne Alternaria rapani and Alternaria brassicicola. Can J Microbiol. 33: 850-856.

18. Moubasher AH. (1993). Soil fungi in Qatar and other Arab countries. Doha, Qatar: The Scientific And Applied Research Centre University of Qatar, 1-566.

19. Elkhateeb WA. (2005). Some mycological, phytopathological and physiological studies on mycobiota of selected newly reclaimed soils in Assiut Governorate, Egypt (M. Sc. Thesis, Faculty of Science, Assuit University, Egypt. 2005; p 238.

20. Kirk PM, Cannon PF, Minter DW, Stalpers JA. (2008). Dictionary of fungi (10th ed.), ISBN 978-085199-826-8. 2008: 1-131.

21. Larone, D. H. (1995). Medically Important Fungi - A Guide to Identification, 3rd ed. ASM Press, Washington, D.C.

22. Abdel-Azeem AM, Blanchette RA, Held BW. (2020). Chaetomium as Potential Soft Rot Degrader of Woody and Papery Cultural Heritage. In Recent Developments on Genus Chaetomium (pp. 395-419). Springer, Cham.

23. Hoog GS, Guarro J, Gene J, Figueras M. (2000). Atlas of Clinical Fungi, 2nd ed, vol. 1. Centraalbureau voor Schimmelcultures, Utrecht, The Netherlands

24. Hamed SR, Abdel-Azeem AM, Dar PM. (2020). Recent Advancements on the Role of Biologically Active Secondary Metabolites from Chaetomium. In Recent Developments on Genus Chaetomium (pp. 177-204). Springer, Cham.

25. Tawfik NF, Ahmed F, Tawfike, Randa Abdou, Grainne Abbott, Usama R. Abdel Mohsen Ru, Edrada-Ebel A, Eman G. Haggag (2017). Metabolomics and Bioactivity Guided Isolation of Secondary Metabolites from the Endophytic Fungus Chaetomium sp. JAPR, 1(1): 66-74

26. Zhang Q, Li HQ, Zong SC, Gao JM, Zhang AL. (2012). Chemical and bioactive diversities of the genus Chaetomium secondary metabolites. Mini reviews in medicinal chemistry, 12(2): 127-148.

27. Li G, Zhang K, Xu J, Dong J, Liu Y. (2007). Nematicidal substances from fungi. Recent Patents on Biotechnology, 1(3): 212-233.

28. Miedtke U, Kennel W. (1990). Athelia bombacina and Chaetomium globosum as antagonists of the perfect stage of the apple scab pathogen (Venturia inaequalis) under field conditions/Athelia bombacina und Chaetomium globosum als Antagonisten des Perfektstadiums des Apfelschorferregers (Venturia inaequalis) unter Feldbedingungen. Zeitschrift für Pflanzenkrankheiten und Pflanzenschutz/Journal of Plant Diseases and Protection, 24-32.

29. Guang LX. (1999). Testing on the antagonism of the dominant of Endophytic fungi from Populas tomentosa: Chaetomium ND 35 in the laboratory. J Scientia Silvae Sinicae. 35(5): 57-61.

30. Tomilova OG, Shternshis MV. (2006). The effect of a preparation from Chaetomium fungi on the growth of phytopathogenic fungi. Appl. Biochem. Microbiol, 42: 76e80.

31. Biswas SK, Srivastav KD, Aggarwal R, Dureja P, Singh DV. (2000). Antagonism of Chaetomium globosum to Drechslera 
sorokiniana, the spot blotch pathogen of wheat. Indian Phytopath. 53(4): 436-440.

32. Soytong K, Kanokmedhakul S, Kukongviriyapa V, Isobe M. (2001). Application of Chaetomium species (Ketomium®) as a new broad spectrum biological fungicide for plant disease control: A review article. Fungal Diversity, 7: 1-15.

33. Aswini C. (2019). A review on Chaetomium globosum is versatile weapons for various plant pathogens. Journal of Pharmocognosy and Phytochemistry, 8(2): 946-949.

34. Moya, P., Cipollone, J., Sisterna, M. (2020). The Fungal Genus Chaetomium and Its Agricultural Applications. Plant Defence: Biological Control, 289-308.

35. Di Pietro A, Gut-Rella M, Pachlatko JP, Schwinn FJ. (1992). Role of antibiotics produced by Chaetomium globosum in biocontrol of Pythium ultimum, a causal agent of dampingoff. Phytopathology, 82(2): 131-135.

36. Madbouly AK, Abdel-Wareth MT. (2020). The Use of Chaetomium Taxa as Biocontrol Agents. In Recent Developments on Genus Chaetomium (pp. 251-266). Springer, Cham.

37. Zhao SS, Zhang YY, Yan W, Cao LL, Xiao Y, Ye YH. (2017). Chaetomium globosum CDW7, a potential biological control strain and its antifungal metabolites. Microbiology Letters, 364(3): fnw287.

38. Gao W, He Y, Li F, Chai C, Zhang J, Guo J, Zhang Y. (2019). Antibacterial activity against drug-resistant microbial pathogens of cytochalasan alkaloids from the arthropod-associated fungus Chaetomium globosum TW1-1. Bioorganic chemistry, 83: 98104.

39. Kumar VS, Kumaresan S, Tamizh MM, Islam MI, Thirugnanasambantham K. (2019). Anticancer potential of NF-kB targeting apoptotic molecule "flavipin" isolated from endophytic Chaetomium globosum. Phytomedicine, 61: 152830.

40. Moubasher, H., and Hamed, E. (2015). Anticancer compounds from Chaetomium globosum. Biochemistry and Analytical Biochemistry, 4(2): 1-10.

41. Wang Z, Xue R, Cui J, Wang J, Fan W, Zhang H, Zhan X. (2019). Antibacterial activity of a polysaccharide produced from Chaetomium globosum CGMCC 6882. International journal of biological macromolecules, 125: 376-382.
42. Wang, X, Houbraken J, Groenewald J, Meijer M, Andersen B, Nielsen K, Crous P, Samson R, (2016). Diversity and taxonomy of Chaetomium and Chaetomium-like fungi from indoor environments. Studies in Mycology, 84: 145-224.

43. Akone SH, Mándi A, Kurtán T, Hartmann R, Lin W, Daletos G, Proksch, P. (2016). Inducing secondary metabolite production by the endophytic fungus Chaetomium sp. through fungal-bacterial co-culture and epigenetic modification. Tetrahedron, 72(41): 6340-6347.

44. Ancheeva E, Küppers L, Akone SH, Ebrahim W, Liu Z, Mándi A, Kalscheuer R. (2017). Expanding the Metabolic Profile of the Fungus Chaetomium sp. through Co-culture with Autoclaved Pseudomonas aeruginosa. European Journal of Organic Chemistry, 2017(22): 3256-3264.

45. Nitao J, Meyer S, Chitwood D, Schmidt W, Oliver J. (2002). Isolation of flavipin, a fungus compound antagonistic to plantparasitic nematodes. Nematology, 4(1): 55-63.

46. Li GY, Li BG, Yang T, Yan JF, Liu GY, Zhang GL. (2006). Chaetocochins A- C, Epipolythiodioxopiperazines from Chaetomium cochliode. Journal of natural products, 69(9): 13741376.

47. Hu Y, Zhang W, Zhang P, Ruan W, Zhu, X. (2012). Nematicidal activity of chaetoglobosin A produced by Chaetomium globosum NK102 against Meloidogyne incognita. Journal of agricultural and food chemistry, 61(1): 41-46.

48. Khan B, Yan W, Wei S, Wang Z, Zhao S, Cao L, Ye Y. (2019). Nematicidal metabolites from endophytic fungus Chaetomium globosum YSC5. FEMS microbiology letters, 366(14): fnz169.

49. Wei MY, Li D, Shao CL, Deng DS, Wang CY. (2013). ( \pm )Pestalachloride D, an antibacterial racemate of chlorinated benzophenone derivative from a soft coral-derived fungus Pestalotiopsis sp. Mar. Drugs, 11: 1050-1060.

50. Wijeratne EK, Turbyville TJ, Fritz A, Whitesell L, Gunatilaka AL. (2006). A new dihydroxanthenone from a plant-associated strain of the fungus Chaetomium globosum demonstrates anticancer activity. Bioorganic \& medicinal chemistry, 14(23): 7917-7923.
This work is licensed under Creative Commons Attribution 4.0 License

To Submit Your Article Click Here: Submit Manuscript

DOI: $10.31579 / 2693-7247 / 030$
Ready to submit your research? Choose Auctores and benefit from:

* fast, convenient online submission

* rigorous peer review by experienced research in your field

* rapid publication on acceptance

* authors retain copyrights

* unique DOI for all articles

* immediate, unrestricted online access

At Auctores, research is always in progress.

Learn more www.auctoresonline.org/journals/pharmaceutics-andpharmacology-research 